\title{
The Level of Using the Technological Innovations of Enterprises and R\&D Activities: The Case of Iron-Steel Enterprises in Turkey
}

\author{
Mehmet Karahan (Corresponding author) \\ Malatya Vocational School, Inonu University \\ Inonu cad, No: 226, 44100, Malatya, Turkey \\ Tel: 90-422-211-8677 E-mail: mkarahan@msn.com \\ Izzettin Ulusoy \\ Tourism Vocational School, Mustafa Kemal University \\ 31100, Hatay, Turkey \\ Tel: 90-506-560-0634 E-mail: iulusoy@mku.edu.tr \\ Accepted: June 8, $2011 \quad$ Published: November 1, 2011 \\ URL: http://dx.doi.org/10.5539/ijbm.v6n11p87
}

Received: April 14, 2011

doi:10.5539/ijbm.v6n11p87

\begin{abstract}
The main goal of this study is to get information about the R\&D process and technical innovations of the iron-steel enterprises and to determine to the ways to improve their current status. This study focuses on 49 SMEs enterprises chosen at random, which are among the total 74 enterprises in Iskenderun. The results of this study are that the middle scale enterprises in the sector have been working for domestic/abroad for a long time and that they are present in R\&D studies and innovations in order to protect their market shares and their rivalries and that they give importance to produce in a certain level of standard and quality. 10 out of 49 enterprises in the region have R\&D unit and there are very few workers in these units, therefore it has been interpreted that the enterprises are insufficient in R\&D.
\end{abstract}

Keywords: The technological innovation, Innovation of product, Production technologies, R\&D

\section{Introduction}

The dynamics emerged from globalization has caused many changes on the environment in which the organizations are active. It is natural that the organizations have been influenced by these changes and they have had to continuously renew their products, structures, systems and strategies in order to be adapted to this change. It is obvious that the business enterprises are luckier than their rivals which can benefit from the opportunities by giving importance to innovations and creativeness and which acquire new costumers and which create new values innovations sees the environment as the source of struggle and it works to understand the change, to make innovation, to apply new ideas and to risk in order to control the environmental changes. For this reason, the innovation is the main method to create opportunity to be a leader business and to develop the performance (Naktiyok, 2007).

The indefinite environment in the market caused by structural change requires a change which needs to use rapidly new technologies. Using new technology will bring innovation of product, service and process for an organization. As a result of this, the organizations will have important advantages by producing products and service different than their rivals (Tekin et al., 2007). But in our time, the rivalry is so that even the innovations made for the necessities of customers are seen as insufficient. The business enterprises wanting to make more innovations than their rivals also investigate the probable necessities if their customers. Besides, they also compete to discover the innovations which increase the wealth of customers (Durna, 2002). In order to realize the innovation activities effectively, there should be a systematic substructure of information in a firm. The two elements of innovation are the importance valued for information and the education level (Topal and Kurt, 2008).

Firms, by creating better values for customers in markets, try to be further on than their rivals. For this, they apply one of these strategies; focusing on cost, cost leadership, focusing on difference (Porter, 1985). At this point, innovation enables the firm to be different from its rivals and it enables the firm to have lesser cost and so the firm catches the rivalry superiority (Higgins, 1996). In other words, competing strategies are important sources which present the firms the opportunity to use two strategies at the same time. They are to be different from the rivals and have a leadership of cost (Bulbul, 2007).

The technological innovation is generally defined as the activities of discovery, improvement and presenting to markets which provide new products, processes or services to be shown in markets. The technological innovation begins as a discovery. If a technological innovation emerges as a result of a will of technical progress, it is called as technological compel; if a technological innovation realizes to meet the necessity of a special market it is called as market pulling. A successful innovation consisted of market pulling or technological compels, should both provide technique superiority in the market and it should produce products which have competing and high quality prices (Simsek and Akin, 2003). 
The technological innovation emerges when an organization makes some changes in its producing a product or service. Innovation is related to both new products and production processes. The aim is to create a value for consumers or customers as a result of the innovation by reducing costs or making different products (Tekin and Omurbek, 2004). The technological innovations are the changes which increase the quality and quantity of products and services and which provide new industry fields and new employment fields. For this reason, the technological innovations directly influence the improvement of economy, the increase in the level of wealth of the society (Roger, 1998). After the technological innovation, investigation, improvement and invention, the business becomes more effective than old technology and methods. Then the technological innovation is used in the economy field. In another words, the first field the technological innovation is used is economic process (Acar, 1992).

The indicator of technological innovation is the developments in the production technologies. If a business enterprise wants to be productive in production, it should renew its production technologies in accordance with the technological innovations (Tekin et al., 2004). The technological innovations are the important vehicles which contribute developing economies to realize their aims (Attaran, 1996).

One of the important results of globalization is the increase in the alternatives of consumers and the markets which require investigation and improvement. One of the main elements which determine the power of rivalry is to make innovations related to $\mathrm{R} \& \mathrm{D}$ and to shorten the period between demand and production, conception and market (Mucuk, 2001). Today, none of the business enterprises or international economies leaves their progresses to coincidence. So, countries and business have to give importance to R\&D. R\&D function is very important for business because they need to solve their problems, to find new production methods and to improve existing production methods (Simsek and Akin, 2003).

$R \& D$ is generally defined as using scientific and technical information in new applications. $R \& D$ has two main elements. The first one is investigation. Whereas main investigation is used for the aims, practical investigation is used by industrial business enterprises fort he aims they valve. R\&D's second element is improvement. It aims to get better results in application and to use know things. In another words, in improvement there is not a discovery; it just involves activities done to trans-form the results of both two investigations into products, systems, production processes and services. So, improvement activities serve as a bridge between investigation activities and production activities (Mucuk, 2001).

New product improvement which has a strategic importance for growth and development of business enterprises is a complex field related to both production and marketing. R\&D activities for new product improvement are not only related to creating a new original product. Attracting the consumers by making an existing product better and more useful is also a method used widely. In this way, a partly change in a product with little cost can be in the quality, elegance, packing, store and use conditions (Mucuk, 2001).

R\&D works can be regional, local and global which are done to reach innovation. In fact, innovation itself is a universal fact and for this reason it is necessary to look at both $R \& D$ works and the factors influencing the innovation with international points of view in order to estimate the innovation. If we want the ice in the poles not to melt, we have to move together with the world by making sacrifices all we have. For this we should know all we have and also know what we can do in how much time. This means that international data are needed to estimate the innovation and R\&D and that the estimation of these data at the same standard is also needed (Arsan, 2008).

The expenditures made for the R\&D activities are important investments. They are related to the growth of the business enterprise. Financial sources required for the activities in the field of R\&D can be met from the profits obtained from technological innovations. And also, R\&D activities influence profits. Therefore, to increase the demand for investment in the field of R\&D is accepted as a strategy. Applying the technological information to industry and the increase of value of product, increase the power of rivalry of product. For this reason, profit is higher than the investment made for R\&D (Tekin and Omurbek, 2004).

The dimensions of the activities of $R \& D$ are examined by profiting from the signs of R\&D expenditures and R\&D human resources. In the developed economies approximately $\% 3$ of gross national products is left for R\&D expenditures. Besides, this doesn't reach at even \%1 in the countries which haven't completed the development process because in these countries sources are primarily used for necessity needs. This situation causes the information gap between the developed and developing countries increase. In the developed countries, R\&D activities are made by private sector which is open to innovations and which has a power of rivalry in the international markets. In the developing countries, these activities are mostly supported by universities and public sectors. The reason of this is that private sectors don't have fund to support these activities. And also, in the developing countries, private sector firms don't have the conscious about this subject (Atik, 2005).

R\&D activities cause not only education but also information production. Whereas education is important for training people who can produce information, $R \& D$ is important for people's reach to new information. $R \& D$ is necessary for getting theoretical information and for the technological developments based on theoretic information. Countries give importance to the increase of R\&D activities as well as education. In the developed societies, power of people joined to R\&D expenditures and AR-GE activities has been increasing continuously (Atik, 2007).

What can be done in Turkey about R\&D is to spend efforts in skill building and innovation for the aim of catching the customers' technologies. R\&D is a complex issue. For people who don't know exactly $R \& D$, it is a dangerous field. $R \& D$ is a cumulative learning process and its probable results are based on past accumulation. Old experiences and existing power of person are the signs of what kind of R\&D can be made later. In our time, R\&D needed for the firms 
in Turkey is a kind of activity to catch up existing technology and to produce cheaper (Kırım, 2007). In Turkey, the industry regions go on living in a global rivalry environment if they improve R\&D studies (Koroglu, 2005).

\section{Materials and methods}

The aim of the study is to determine the states in the R\&D works and the technological innovation of the enterprises in the iron-steel sector in Iskenderun and to determine these enterprises development potential. There are total 74 enterprises registered in trade association in the iron-steel sector in Iskenderun. In this study, 49 example enterprises have been chosen and these represent all the iron-steel enterprises.

The face to face survey method has been chosen as a means to get data in the study. Some surveys used in the previous studies have been examined (Durna, 2002; Taymaz, 2004; Bulbul, 2007; Naktiyok, 2007 and TUIK, 2008) and "The technological innovation and R\&D investigation survey form" has been developed. This survey has three sections. These are; a. The demographic features of the enterprises joined to the investigation, $b$. The states of the use technological innovations of the enterprises, $\mathrm{c}$. The information about R\&D studies.

There are total 67 questions in the survey. The Alpha reliability coefficient is 0.71 of these questions. According to this result, it can say that our survey is reliable. At the end of the survey application, data obtained from 49 enterprises have been transferred to SPSS pocket program and statistical evaluation of them has been made.

\section{Results and discussions}

In this section, in sequence, the demographic features of the business in the research, the levels of use the technological innovations of the business, the ideas of enterprises, about R\&D studies and the findings about determining, R\&D studies have been evaluated.

\subsection{Demographic profiles}

People's positions in the enterprises who answered the questions in the poll;12\%(6) of people are factory manager, $6 \%(3)$ are product manager, $6 \%(3)$ are R\&D manager, $4 \%(2)$ are data processing manager, $8 \%(4)$ are marketing managers and $55 \%(27)$ are others. So, it can be said that the majority of people who answered the questions in the survey are other managers (business owner, engineer, head workman etc.).

The enterprises sectors in the survey; almost total are metal products sector and machine industry sector $94 \%(46)$. Only $6 \%(3)$ have marked the others alternative but it is known that they are also the enterprises in the by-industry of the iron-steel sector. So, it can be said that all the enterprises in the research are in the iron-steel sector in Iskenderun.

The number of workers in the enterprises; between 10-49 are $39 \%$ (19), between 50-99 are $20 \%(10), 100$ and above 100 are $41 \%(20)$. According to this, it can be concluded that the majority of the workers in Iskenderun iron-steel sector enterprises are 100 and above 100 people and that most of the enterprises in the iron-steel sector are small and middle scale enterprises (SME).

$6 \%(3)$ of the enterprises have been active for $0-2$ years, $12(6) \%$ of them has been active for $3-5$ year, $12 \%(6)$ of them for 6-8 years, $16 \%(8)$ of them for $9-11$ years and $53 \%(26)$ of them for 12 years and above. It can be said that mast of the business enterprises in the iron-steel sector in Iskenderun have been active for 12 years and above and they are experienced in that sector.

$39 \%(19)$ of the enterprises joined the investigation only address to domestic markets, $6 \%(3)$ of them addresses to only abroad markets and $55 \%(27)$ of them address to both domestic and abroad markets. So, it can be said that the majority of these business enterprises in Iskenderun addresses to both domestic and abroad markets.

$10 \%(5)$ of the enterprises in the research have the patent of ideal property right, $2 \%(1)$ of them have industrial conception, $43 \%(21)$ of them have trademark, $2 \%(1)$ have copyright, and $43 \%(21)$ of them haven't any trademark. So, it can be concluded that the majority of these enterprises in Iskenderun has at least one trademark right and that nearly half of them has no ideal property right.

$61 \%$ (30) of the enterprises in the research have the ISO 9000 quality certificate, $24 \%$ (12) of them haven't this certificate and $14 \%$ (7) of them have the application for this certificate. $84 \%$ (41) of these enterprises have the TSE quality certificate, $12 \%$ (6) of them haven't this certificate and $4 \%$ (2) of them have the application for this certificate. It can be said that the majority of these business enterprises in the iron-steel sector in Iskenderun has the ISO 9000 and TSE quality certificates.

\subsection{The findings about the levels of use the technological innovations of the enterprises}

In this section, some findings have been evaluated about the rates of making innovations of the iron-steel enterprises in Iskenderun, their innovation kinds they made, their reasons for making innovations, the factors which encouraging innovations and commercial using the products. As it is seen in the Table 1, some questions have been asked to enterprises about the innovations they have made in the last five years.

In the first section, it has been observed that about 43\% (21) of the enterprises in the investigation have used new technologies, 39\% (19) of them have used old technologies and 12\% (06) have used old technologies. This situation can be interpreted as they renew their technologies in time and they have new technologies although they are old enterprises.

In the second section, the enterprises states of developing new products have been examined. $47 \%$ (23) of them have made product innovation at middle level, $16 \%(08)$ of them have made very much product innovation and $14 \%(07)$ of them have made little product innovation. According to this, the majority of these enterprises have 
made production innovation.

In the third section, the states of process innovation of the enterprises have been asked. $47 \%$ (23) of them have made process innovation at middle level, 39\% (19) very much, $10 \%(05)$ very little. According to these results, the majority of the enterprises have made process innovation in the last five years.

In the fourth section, vain results of the technological innovation activities of the enterprises that they have made in the last five years have been examined. According to the results, $78 \%$ (38) of the enterprises didn't experience this situation, $16 \%(08)$ of them had a few vain results and $4 \%(2)$ of them experienced many vain results. According to this, the majority of them didn't experience any negativity in the process of innovation.

In the fifth section, the enterprises which continue the innovation activities have been examined. $35 \%$ (17) of them usually continue these activities, $31 \%$ (15) continue at middle level, $18 \%$ (9) of them continue these activities at advanced level. According to this, the majority of the enterprises go on these activities at advanced level.

In the sixth section, the states of making organization changes of the business enterprises have been investigated. According to the results, 37\% (18) of the business enterprises have made organization changes at middle level, $26 \%$ (13) of them have made very few changes and $24 \%$ (12) of them have made many organization changes. According to this, it can be said that the majority of them have made organization changes at middle and advanced levels.

In the seventh section, the states of making changes in marketing of the enterprises. According to the data, $33 \%$ (16) of them have made great marketing changes, $29 \%$ (14) of them have made changes at middle level, 26\% (13) of them have made changes at advanced level. According to this, the majority of them have made organization changes at advanced level.

In the eighth section, the states of making changes in input procuring and in the distribution canals of the business enterprises. According to the data, $39 \%$ (19) of them have made these changes at middle level, $33 \%$ (16) of them have made many changes, $20 \%$ (10) have made few changes in input procuring and in distribution canals. According to this, the majority of the business enterprises in the investigation have made changes in input procuring and in distribution canals.

As it is seen in Table 2, the kinds of changes the business enterprises have made in the last five years has been asked. In the first section, according to the data, 29\% (14) of the business enterprises have made product change at middle level, $29 \%$ (14) of them have made few changes and $24 \%$ (12) of them have made many changes. In the second section, $43 \%$ (21) of the business enterprises have expressed that they have made service innovation at middle level, $33 \%$ (16) of them have made many innovations and $16 \%$ (8) of them have made innovation at advanced level. In the third section, it is seen that $39 \%$ (19) of the enterprises have made great innovations in the process of production, $22 \%$ (11) of them have made innovation at middle level, $20 \%$ (10) of them have made innovation at advanced level. In the fourth section, it can be said that $41 \%$ (20) of the enterprises have made innovations in the process of logistic, distribution and delivering at middle level, $26 \%$ (13) of them have made many innovations, $20 \%$ (10) of them have made few innovations. In the fifth section, $49 \%$ (24) of the business enterprises have made innovations related to the processes of supporting activities at middle level, $29 \%$ (14) of them have made many innovations and $12 \%$ (6) of them have made innovations at advanced level. The Table 2 generally shows that the kinds of innovations the business enterprises have made are generally the innovations of production process and then the innovations of supporting activities.

As it is seen in the Table 3, the reasons of why the business enterprises have made innovations have been asked them. In the first section, $35 \%$ (17) of the business enterprises have stated that the rival firms have forced them too much to make innovations, $31 \%$ (15) of them have been forced much and 26\%(13) of them have been forced at middle level. In the second section, 35\%(17) of the business enterprises have made too many innovations because of changing needs and demands of customers,35\%(17) of them have made many innovations and $26 \%(13)$ of them have made innovations at middle level. In the third section, it is stated that $35 \%(17)$ of the enterprises have made innovations at middle level because of changing technologies, 33\% (16) of them have made innovations at advanced level and $26 \%(13)$ has made innovations at extremely advanced levels. In the fourth section, it is stated that $41 \%$ (20) of the business enterprises have made innovations at middle level because of changes in the structure or casts of inputs, $31 \%(15)$ have made innovations at advanced level and $18 \%$ (9) have made many innovations. In the fifth section, 37\% (18) of the business enterprises have made innovations at middle level because of the decrease in demands of old products, 24\% (12) have made innovations at great amount and 20\% (10) have made innovations at advanced level. In the sixth section, it is stated that $41 \%(20)$ of the business enterprises have made innovations at advanced level in order to enter new markets, $31 \%$ (15) of them have made many innovations and 24\%(12) of them have made innovations at middle level. In the seventh section, it is seen that $47 \%$ (13) of the business enterprises have made many innovations to use the sources productive, $33 \%(16)$ of them have made innovations at advanced level, $16 \%(8)$ have made innovations at middle level. The Table 3 generally shows that the reasons of the enterprises in the research making innovations are generally using the sources productively and then entering the new markets.

As it is seen in the Table 4, the question by which the innovations have been realized has been asked to the business enterprises. In the first section, $63 \%$ (31) of the enterprises have stated that the innovations have been realized today by themselves, in the second section, $37 \%$ (18) of them have stated that the innovations have been 
realized in the last three years by them and other firms, in the third section, $75 \%$ (37) of them have stated that they have realized innovations without any help of other firms and institutions. Generally the Table 4 shows that most of the business enterprises in the research have realized the innovations themselves and without any help from outside.

As it is seen in the Table 5, the importance degree of the factors which encourage the enterprises to make innovations has been asked to them. In the first section, most of the enterprises have expressed that they give importance to meet the demands and needs of customers, in the second section, the enterprises have stated that they give importance to answer the attacks of their rivals back at advanced level, in the third section, the business enterprises have stated that they give importance to their prestige and image, in the fourth section, the business enterprises have stated that they give importance to the decrease in the demands of existing products, in the fifth section, they have stated that they are give importance to improve their production skills. The Table 5 generally shows that the importance that the business enterprises give to the factors which encourage them to make innovations can be arranged in a row as firstly answering the attacks of rivals back and secondly meeting the demands and needs of customers.

As it is seen in the Table 6, business enterprises have determined the degrees of their successes in developing new products and commercializing them. The Table 6 generally shows that the enterprises aren't good enough at developing new products and commercializing them and that they are more successful in developing new products but they aren't successful enough in commercializing these products.

\subsection{The findings related to $R \& D$ studies of the enterprises}

In the study, it has been observed that $20 \%$ (10) of the 49 iron-steel enterprises chosen as sample have R\&D unit, $80 \%$ (39) of them haven't this unit. In this ten business enterprises, the number of workers are as; between 1-4 are $8 \%$ (2) people, between 5-9 are 4\%(2) people, between 10-49 are 4\%(2) people, between $50-99$ are $4 \%(2)$ people. The questions below have been asked to these ten enterprises which have R\&D units and the findings have been shown in the tables below.

As it is seen the Table 7 the reasons of establishing R\&D units have been asked to the enterprises in the research. The Table 7 shows that most of enterprises have established R\&D units in order to meet the demands and needs of customers. The following reason is the attitudes of rivals and the general strategies of the firm.

In the Table 8 , the activities done in R\&D units have been asked to the enterprises in the research. The Table 8 shows that most of the activities in $R \& D$ units of the enterprises are improving the existing technologies. Following activities are operational investigation activities.

In the Table 9 what R\&D units do from the point of view of innovation has been asked to the enterprises. The table 9 generally shows that the activities of R\&D units of the enterprises are generally improving the existing production technologies, new product developing and making products different.

In the Table 10 what R\&D units of the enterprises contributed to administrating has been examined. The table 10 shows that most of the contributions of $R \& D$ units to administrating are the increase of quality, the decrease of costs, and flexibility.

\section{Conclusions}

The enterprises should find their own innovation strategies in order to survive successfully in the environment of rivalry in today's world. The factors such as circumstances of the environment, the rivalry strategy of the enterprises and the sources they have play an important role in determining the innovation strategies. One of the factors influencing the innovation is also the organizational structure of the enterprises. The enterprises which have innovative organizational structure will also have innovative strategies (Durna, 2002).

Innovations realizes in the environments in which people can express their ideas and thoughts freely. Innovative enterprises, managers should regard a new idea, suggestion or an application as a rich source and they should say "why not" for an original idea. The communication should be perfect in enterprises to benefit from innovations effectively. Innovations should be realized in free environments because they are risky. They may be seen as a challenge for the status quo because they can cause big changes. They require tolerance because they can criticize existing applications.

Workers should be motivated in order not to give up after many fault trials because innovations require a long time for studies. For this reason, workers should be rewarded in all processes to make innovations continuous. Workers in innovative business enterprises should be made conscious and educated about administrating strategy and the organizational structure should be flexible and dynamic.

Since the middle scale enterprises in iron-steel sector in Iskenderun have been active for a long time in domestic and world markets, their making innovations and R\&D studies are important for them to produce in a definite standard and quality degree to maintain their market shares and their skills of competing. In this point, whereas it is a positive situation that the majority of them have the ISO 9000 and TSE certificates, it is a negative situation that they are insufficient in transforming their products to trademarks and getting patents.

It can be said that the enterprises in the investigation have made great process innovations in order to use their sources productively and to enter new markets. It is in seen that the enterprises have made innovations usually themselves without any help. This result shows that the enterprises in the region aren't open to outside. But today's circumstances require that they should improve their abroad and domestic collaborations with other 
enterprises in the sector in order to enter new markets and to get rivalry superiority. Improving new strategies is very important for them to extend their administrating process.

It is accepted as a contradiction that the majority of the business enterprises give priority to answer the rival's attacks back which encourages them to make innovations but they don't give enough importance to make collaboration with domestic and abroad enterprises. They should have close relationships with other enterprises sector activities and their customers in order to answer their rivals' attacks back and to meet the demands of their customers in time.

It can be said that the enterprises aren't successful in producing new products because they don't give enough importance to R\&D studies. The business enterprises may have the markets snatched to their rivals if they don't renew and make difference in their existing products. The theories "Creating worth" of Doyle (2003), "Priorities of rivalry" of Porter (2008) and "Sur petition" of De Bono (1996), reevaluate their strategies by thinking these theories.

The evidence of the inadequate of the enterprises in $R \& D$ is that 10 of the 49 enterprises don't have R\&D units and that there are not enough workers in these units. But it depends on R\&D studies of the enterprises to renew their products, to develop new products and to compete with their rivals. The enterprises don't collaborate enough with domestic and abroad institutions in R\&D studies as well as in making innovations and this will make them have difficulty in today's rivalry environment. However, as it is known from abroad enterprise examples, although the enterprises don't find it economical to establish their own R\&D units, they can compensate for this need collaborating with other people institutions. Today, even the enterprises regarded as the leaders of markets of the worldwide sometimes need help of other institutions which are professional in their R\&D studies and they sometimes have self interest collaborations with their rivals. So, they have profits in economy and also they have the opportunity to ideal with their own profession fields.

The enterprises give priority to developing activities among R\&D activities and this means that they don't find R\&D activities worthy enough. However, the enterprises can be the leaders of markets by improving their existing products, giving importance to investigation activities and producing new products and strategies. It can be said that the results about the contributions of R\&D units to the business enterprises are consistent. R\&D provides the increase of rivalry power and quality for the enterprises as stated by many theorists (Porter, 2008; Gules and Bulbul, 2004; Tekin and Zerenler, 2009; Tekin et al., 2007; Akgemci, 2008). It is a positive situation that the enterprises in the region have this conscious.

\subsection{Suggestions}

After general evaluations and interpretations, it is possible to make suggestions about the determined situations and problems of the enterprises.

- The needed studies of law to support such as tax discounts and new credit opportunities should be renewed in order to encourage the business enterprises.

- The local managements should constitute their innovation strategies. The subjects such as R\&D standards, estimating, evaluation and sharing the best applications and making them widespread should be established horizontal relationships with other operation plans. Informing and being aware studies should be done in order to be close to society (Arsan, 2007).

- Innovation culture and innovation approaches should be accepted as a lifestyle by society through spreading them to all over the country in order to improve innovation and reach it to the needed degree. The important factors in spreading the innovation culture are increase of the data flow, the experts in universities taking place in industry institutions.

- The State can overcome with the problems by providing people who favors change financial helps, establishing R\&D institutions, providing the coordination's among institutions, supporting the collaboration of university-industry, encouraging the innovations' spreading, reorganizing the education system according to today's circumstances and making legal arrangements.

- In order to increase the R\&D expenditures, firstly, the enterprises or industry regions should establish shared R\&D units, and secondly, professional associations should encourage and support them.

- The units can be formed which work together with R\&D unit in our universities, work by following our enterprises continuously, make statistical studies and follow and solve the problems of our enterprises. People can consult our universities about this subject.

- It is required to decrease bureaucracy in the support of national R\&D and innovation provided for firms and to be objective and transparent in evaluations. Many small firms which can sign important project lose their trusts and courage because of bureaucracy and they can't benefit from these supports. So, bureaucracy should be decreased and evaluations should be made objectively (Vardar, 2007).

\section{References}

Acar, N. (1992). Full time production system and Kanban. Ankara: MPM Publishing.

Akgemci, T. (2008). Strategic management, (2nd Edition). Ankara: Gazi Publishing.

Arsan, L. (2007). Facilitate people's lives... This means that innovation. [Online] Available: http://www.bilgicagi.com/index.php?option=com_content\&task=view\&id=123\&Itemid=139\&limit=1\&limitstart 
$=0$ (July 20, 2008).

Arsan, L. (2008). Do not see the truth cannot reach the right conclusion. The information age. e-journals. [Online] Available: http://www.bilgicagi.com/index.php?option=comcontent\&task= view\&id=93\&Itemid=139 (June 10 , 2008).

Atik, H. (2005). Innovation and national competitiveness, 1st Edition. Ankara: Detay Publishing.

Atik, H. (2007). Dynamics and Technological Development of the Information Society (Editor: Rifat Yildiz), Functionality Universities Research and Application Centers. Ankara: Detay Publishing.

Attaran, M. (1996). Barriers to Effective CIM Implementation. Information System Management, 13, 4, 65-81.

Bulbul, H. (2007). Great Food Industry Firms Competitive and Innovative Practices in Turkey. Hacettepe University Journal of Economics and Administrative Sciences, 25, 1, 91-120.

De Bono, E. (1996). Sur Petition, (Translate by: Oya Ozel). Istanbul: Remzi publications.

Demir, O. (2007). New Models of Growth and Technological Development, (Editor: Rifat Yildiz). Functionality Universities Research and Application Centers. Ankara: Detay Publishing.

Doyle, P. (2003). Value-based marketing, (Translated: Gülfidan Baris). Istanbul: Capital Media Services.

Durna, U. (2002). Innovation management, (1 $1^{\text {st }}$ ed.). Ankara: Nobel publication distribution.

Gules, Hasan K., \& Bulbul, H. (2004). Innovation: The strategic competitive tool for businesses (1 ${ }^{\text {st }}$ ed.). Ankara: Nobel publication distribution.

Higgins, J. M. (1996). Innovate or Evaporate: Creative Techniques for Strategist. Long Range Planning, 29, 3, 370-380. http://dx.doi.org/10.1016/0024-6301(96)00023-4

Kirım, A. (2007). Turkey How rich? (1st ed.). Istanbul: Remzi publication.

Koroglu, Bilge A. (2005). Indicators of innovation and innovation processes in SMEs in the industrial regions of Turkey. Gazi University Journal of Science, 18, 4, 693-706

Mucuk, I. (2001). Basic business information, (1st ed.). Istanbul: Turkmen book house.

Naktiyok, A. (2007). Innovation orientation and organizational factors. Ataturk University Faculty of Economics and Administrative Sciences Journal, 21, 2, 25-40

Porter, M.E. (1985). Competitive Advantage: Creating and Sustaining Superior Performance. New York: The Free Press.

Porter, M.E. (2008). Competitive strategy, sector and competitive analysis techniques, (Translated by: Gulen Ulubilgen). Istanbul: Sistem Publishing.

Roger, W S. (1998). Operating management. Business horizons, 41, 3, 121-134

Simsek, M.S., \& Akın, H.B. (2003). Technology management and organizational change, $1^{\text {st }}$ ed. Konya: Cizgi Bookstore.

Taymaz, E. (2004). Turkey technological capability in the manufacturing industry. National Vision 2023 Technology Inventory Project Report, Ankara: TUBITAK.

Tekin, M., \& Omurbek, N. (2004). Applications in the automotive sector in the global competitive environment and technological cooperation. Selcuk University IIBF Press, Konya, Turkey.

Tekin, M., \& Zerenler, M. (2009). Competition Key: Flexible Business. Konya, Turkey: IIBF Publications.

Tekin, M., Gules, Hasan K., \& Ogut, A. (2007). Changes in the age of technology management, (4th ed.). Ankara: Gazi Bookstore.

Topal, Y., \& Kurt, M. (2008). Competitive strategies of SMEs in the process of the European Union: Innovation strategy. [Online] Available: http://www.bilgiyonetimi.org/cm/pages/?nt=383 (July 20, 2008).

TUİK. (2007). Industrial service organizations, research and development survey. Department of industry and business statistics. [Online] Available: http://www.tuik.gov.tr (April 21, 2009).

Vardar, F. (2007). What should be done for the development of innovation zones in Turkey? Information Age magazine. [Online] Available: http://www.bilgicagi.com/index.php?option=com_content\&task $=$ view\&id=103\&Itemid= 139 (July 20, 2008). 
Table 1. The last 5 years, rates of innovation of enterprises

\begin{tabular}{|c|c|c|c|}
\hline Question & Options & $\mathrm{F}$ & $\%$ \\
\hline \multirow{5}{*}{ 1. Type of technology used in the enterprise } & Very old & 01 & 02.0 \\
\hline & Old & 06 & 12.2 \\
\hline & Moderate & 19 & 38.8 \\
\hline & New & 21 & 42.9 \\
\hline & Very new & 02 & 04.1 \\
\hline \multirow{5}{*}{ 2. New product development (product innovation) } & Never & 06 & 12.2 \\
\hline & Rarely & 07 & 14.3 \\
\hline & Moderate & 23 & 46.9 \\
\hline & Very & 08 & 16.3 \\
\hline & More & 05 & 10.2 \\
\hline \multirow{5}{*}{ 3. New production techniques (process innovation) } & Never & 01 & 02.0 \\
\hline & Rarely & 05 & 10.2 \\
\hline & Moderate & 23 & 46.9 \\
\hline & Very & 19 & 38.8 \\
\hline & More & 01 & 02.0 \\
\hline \multirow{5}{*}{$\begin{array}{l}\text { 4. Technological innovation activities have been } \\
\text { unsuccessful }\end{array}$} & Never & 38 & 77.6 \\
\hline & Rarely & 08 & 16.3 \\
\hline & Moderate & 01 & 02.0 \\
\hline & Very & 02 & 04.1 \\
\hline & More & 00 & 00.0 \\
\hline \multirow{5}{*}{ 5. Technological innovation activities in progress } & Never & 02 & 04.1 \\
\hline & Rarely & 06 & 12.2 \\
\hline & Moderate & 15 & 30.6 \\
\hline & Very & 17 & 34.7 \\
\hline & More & 09 & 18.4 \\
\hline \multirow{5}{*}{ 6. Make organizational innovation } & Never & 00 & 00.0 \\
\hline & Rarely & 13 & 26.5 \\
\hline & Moderate & 18 & 36.7 \\
\hline & Very & 12 & 24.5 \\
\hline & More & 06 & 12.2 \\
\hline \multirow{5}{*}{ 7. To innovation in marketing } & Never & 00 & 00.0 \\
\hline & Rarely & 06 & 12.2 \\
\hline & Moderate & 14 & 28.6 \\
\hline & Very & 16 & 32.7 \\
\hline & More & 13 & 26.5 \\
\hline \multirow{6}{*}{ 8. Input supply and distribution channels, innovation } & Never & 00 & 00.0 \\
\hline & Rarely & 10 & 20.4 \\
\hline & Moderate & 19 & 38.8 \\
\hline & Very & 16 & 32.7 \\
\hline & More & 04 & 08.2 \\
\hline & Total & 49 & 100.0 \\
\hline
\end{tabular}


Table 2. Types of innovation in their businesses

\begin{tabular}{|l|r|c|c|}
\hline Question & Options & $\mathrm{F}$ & $\%$ \\
\hline & Never & 04 & 08,2 \\
1. Goods (product) innovation & Rarely & 14 & 28,6 \\
& Moderate & 14 & 28,6 \\
& Very & 12 & 24,5 \\
& More & 5 & 10,2 \\
\hline 2. Services innovation was done & Never & 01 & 02,0 \\
& Rarely & 08 & 16,3 \\
& Moderate & 21 & 42,9 \\
& Very & 16 & 32,7 \\
3. Innovation in production processes were & More & 03 & 06,1 \\
performed & Never & 00 & 00,0 \\
& Rarely & 09 & 18,4 \\
& Moderate & 11 & 22,4 \\
& Very & 19 & 38,8 \\
4. Innovation was made in logistics, delivery and & More & 10 & 20,4 \\
distribution processes & Never & 01 & 02,0 \\
& Rarely & 10 & 20,4 \\
& Moderate & 20 & 40,8 \\
\hline \multirow{2}{*}{ 5. Innovation was made in support activities related } & Very & 13 & 26,5 \\
to the processes & More & 05 & 10,2 \\
\hline & Never & 00 & 00,0 \\
& Rarely & 05 & 10,2 \\
& Moderate & 24 & 49,0 \\
& Very & 14 & 28,6 \\
& More & 06 & 12,2 \\
\hline
\end{tabular}


Table 3. Reasons for making innovation enterprises

\begin{tabular}{|l|r|c|c|}
\hline Question & Options & $\mathrm{F}$ & $\%$ \\
\hline \multirow{4}{*}{ 1. Because of competitors, we need to innovate } & Not important & 00 & 00,0 \\
& Less important & 04 & 08,2 \\
& Important & 13 & 26,5 \\
& Very important & 15 & 30,6 \\
& Too much important & 17 & 34,7 \\
\hline 2. Due to changing demands and needs of consumer & Not important & 00 & 00,0 \\
& Less important & 02 & 04,1 \\
& Important & 13 & 26,5 \\
& Very important & 17 & 34,7 \\
& Too much important & 17 & 34,7 \\
\hline 3. Due to change of the current technology & Not important & 00 & 00,0 \\
& Less important & 03 & 06,1 \\
& Important & 17 & 34,7 \\
& Very important & 13 & 26,5 \\
& Too much important & 16 & 32,7 \\
\hline 4. Due to changes of prices or input structure & Not important & 00 & 00,0 \\
& Less important & 05 & 10,2 \\
& Important & 20 & 40,8 \\
& Very important & 09 & 18,4 \\
& Too much important & 15 & 30,6 \\
\hline 7. For efficient use of resources owned & Not important & 03 & 06,1 \\
& Less important & 06 & 12,2 \\
5. To enter new markets & Important & 18 & 36,7 \\
& Very important & 12 & 24,5 \\
& Too much important & 10 & 20,4 \\
\hline & Not important & 00 & 00,0 \\
& Less important & 02 & 04,1 \\
& Important & 12 & 24,5 \\
& Very important & 15 & 30,6 \\
& Too much important & 20 & 40,8 \\
\hline & Not important & 00 & 00,0 \\
& Less important & 02 & 04,1 \\
& Important & 08 & 16,3 \\
& Too much important & 23 & 46,9 \\
& Total & 49 & 32,7 \\
\hline & & 100.0 \\
\hline & &
\end{tabular}

Table 4. Technological innovation in enterprises by whom it was done

\begin{tabular}{|l|r|c|c|}
\hline Question & Options & $\mathrm{F}$ & $\%$ \\
\hline \multirow{2}{*}{ 1. Innovation was largely in-house. } & Today & 31 & 63,3 \\
& The last years & 09 & 09,0 \\
2. Innovation was held together with other organizations & No answer & 09 & 18,4 \\
\hline \multirow{2}{*}{ 3. Innovation works largely with other organization } & 14 & 28,6 \\
(external) was built & The last years & 18 & 36,7 \\
& No answer & 17 & 34,7 \\
\hline & Today & 08 & 16,3 \\
& The last years & 04 & 08,2 \\
& No answer & 37 & 75,5 \\
\hline
\end{tabular}


Table 5. Severity levels of the factors promoting innovation of enterprises

\begin{tabular}{|l|r|c|c|}
\hline Question & Options & $\mathrm{F}$ & $\%$ \\
\hline \multirow{4}{*}{ 1. Meet customers' demands and expectations } & Not important & 00 & 00,0 \\
& Less important & 00 & 00,0 \\
& Important & 14 & 28,6 \\
& Very important & 19 & 38,8 \\
& Too much important & 16 & 32,7 \\
\hline 2. Respond to competitors' attacks & Not important & 00 & 00,0 \\
& Less important & 01 & 02,0 \\
& Important & 09 & 18,4 \\
& Very important & 19 & 38,8 \\
& Too much important & 20 & 40,8 \\
\hline 3. Image and prestige to win & Not important & 01 & 02,0 \\
& Less important & 09 & 18,4 \\
& Important & 09 & 18,4 \\
& Very important & 16 & 32,7 \\
& Too much important & 14 & 28,6 \\
\hline 4. Reduce demand for existing products & Not important & 01 & 02,0 \\
& Less important & 05 & 10,2 \\
& Important & 12 & 24,5 \\
& Very important & 22 & 44,9 \\
& Too much important & 09 & 18,4 \\
\hline \multirow{5}{*}{ 5. Improve production capabilities } & Not important & 01 & 02,0 \\
& Less important & 02 & 04,1 \\
& Important & 14 & 28,6 \\
& Very important & 16 & 32,7 \\
& Too much important & 16 & 32,7 \\
\hline & Total & 49 & 100.0 \\
\hline
\end{tabular}

Table 6. Success of new product development and commercialization of businesses

\begin{tabular}{|c|c|c|c|}
\hline Question & Options & $\mathrm{F}$ & $\%$ \\
\hline \multirow{5}{*}{$\begin{array}{l}\text { 1. Compare with your competitors, do you think the } \\
\text { success of your business in new product } \\
\text { development }\end{array}$} & Very unsuccessful & 00 & 00,0 \\
\hline & Unsuccessful & 12 & 24,5 \\
\hline & Partially successful & 14 & 28,6 \\
\hline & Successful & 14 & 28,6 \\
\hline & Very successful & 09 & 18,4 \\
\hline \multirow{6}{*}{$\begin{array}{l}\text { 2. Compare with your competitors, do you find your } \\
\text { business successful commercialization of new } \\
\text { products? }\end{array}$} & Very unsuccessful & 01 & 02,0 \\
\hline & Unsuccessful & 13 & 26,5 \\
\hline & Partially successful & 14 & 28,6 \\
\hline & Successful & 15 & 30,6 \\
\hline & Very successful & 06 & 12,2 \\
\hline & Total & 49 & 100.0 \\
\hline
\end{tabular}


Table 7. Reasons for businesses to create R \& D unit

\begin{tabular}{|l|r|c|c|}
\hline Question & Options & $\mathrm{F}$ & $\%$ \\
\hline \multirow{4}{*}{ 1. Attitudes and behavior of competitors } & Not important & 00 & 00,0 \\
& Less important & 00 & 00,0 \\
& Important & 03 & 30,0 \\
& Very important & 05 & 50,0 \\
& Too much important & 02 & 20,0 \\
\hline 2. Meet customer demands and expectations & Not important & 00 & 00,0 \\
& Less important & 00 & 00,0 \\
& Important & 00 & 00,0 \\
& Very important & 02 & 20,0 \\
& Too much important & 08 & 80,0 \\
\hline 3. The company's overall strategy & Not important & 00 & 00,0 \\
& Less important & 00 & 00,0 \\
& Important & 03 & 30,0 \\
& Very important & 03 & 30,0 \\
& Too much important & 04 & 40,0 \\
\hline 4. Other reasons & Not important & 00 & 00,0 \\
& Less important & 05 & 50,0 \\
& Important & 02 & 20,0 \\
& Very important & 03 & 30,0 \\
& Too much important & 00 & 00,0 \\
\hline & Total & 10 & 100.0 \\
\hline
\end{tabular}

Table 8. The R\&D activities in enterprises

\begin{tabular}{|l|r|c|c|}
\hline Question & Options & F & $\%$ \\
\hline 1. Basic research & None & 00 & 00,0 \\
& A little & 03 & 30,0 \\
& Moderate & 02 & 20,0 \\
& A lot & 04 & 40,0 \\
2. Applied research & Much more & 01 & 10,0 \\
\hline & None & 00 & 00,0 \\
& A little & 00 & 00,0 \\
& Moderate & 03 & 30,0 \\
3. Development research & A lot & 05 & 50,0 \\
& Much more & 02 & 20,0 \\
\hline & None & 00 & 00,0 \\
& A little & 00 & 00,0 \\
4. Preliminary design research & Moderate & 01 & 10,0 \\
& A lot & 03 & 30,0 \\
& Much more & 06 & 60,0 \\
\hline & None & 00 & 00,0 \\
& A little & 00 & 00,0 \\
& Moderate & 06 & 60,0 \\
& A lot & 03 & 30,0 \\
& Much more & 01 & 10,0 \\
\hline & Total & 10 & 100.0 \\
\hline
\end{tabular}


Table 9. The evaluation of innovation activities of enterprises in R \& D units

\begin{tabular}{|c|c|c|c|}
\hline Question & Options & $\mathrm{F}$ & $\%$ \\
\hline \multirow{5}{*}{ 1. Current product development and improvement } & Not important & 01 & 10,0 \\
\hline & Less important & 01 & 10,0 \\
\hline & Important & 00 & 00,0 \\
\hline & Very important & 03 & 30,0 \\
\hline & Too much important & 05 & 50,0 \\
\hline \multirow{5}{*}{ 2. To the imitation of product innovations } & Not important & 02 & 20,0 \\
\hline & Less important & 01 & 10,0 \\
\hline & Important & 02 & 20,0 \\
\hline & Very important & 02 & 20,0 \\
\hline & Too much important & 03 & 30,0 \\
\hline \multirow{5}{*}{ 3. Differentiate the product } & Not important & 00 & 00,0 \\
\hline & Less important & 00 & 00,0 \\
\hline & Important & 01 & 10,0 \\
\hline & Very important & 05 & 50,0 \\
\hline & Too much important & 04 & 40,0 \\
\hline \multirow{5}{*}{$\begin{array}{l}\text { 4. The harmonization of market conditions of the } \\
\text { products }\end{array}$} & Not important & 01 & 10,0 \\
\hline & Less important & 01 & 10,0 \\
\hline & Important & 02 & 20,0 \\
\hline & Very important & 00 & 00,0 \\
\hline & Too much important & 06 & 60,0 \\
\hline \multirow{5}{*}{ 5. Develop new products } & Not important & 00 & 00,0 \\
\hline & Less important & 00 & 00,0 \\
\hline & Important & 01 & 10,0 \\
\hline & Very important & 02 & 20,0 \\
\hline & Too much important & 07 & 70,0 \\
\hline \multirow{5}{*}{ 6. Develop new processes } & Not important & 00 & 00,0 \\
\hline & Less important & 00 & 00,0 \\
\hline & Important & 04 & 40,0 \\
\hline & Very important & 03 & 30,0 \\
\hline & Too much important & 03 & 30,0 \\
\hline \multirow{5}{*}{ 7. Improve the existing production technology } & Not important & 00 & 00,0 \\
\hline & Less important & 01 & 10,0 \\
\hline & Important & 00 & 00,0 \\
\hline & Very important & 03 & 30,0 \\
\hline & Too much important & 06 & 60,0 \\
\hline \multirow{6}{*}{ 8. Develop new production technology } & Not important & 00 & 00,0 \\
\hline & Less important & 01 & 10,0 \\
\hline & Important & 02 & 20,0 \\
\hline & Very important & 03 & 30,0 \\
\hline & $\begin{array}{r}\text { Much more } \\
\text { important }\end{array}$ & 04 & 40,0 \\
\hline & Total & 10 & 100.0 \\
\hline
\end{tabular}


Table 10. Benefits of business R\&D unit within the last 5 years

\begin{tabular}{|c|c|c|c|}
\hline Question & Options & $\mathrm{F}$ & $\%$ \\
\hline \multirow{5}{*}{ 1. Reduce costs } & No & 00 & 00,0 \\
\hline & Less & 00 & 00,0 \\
\hline & Moderate & 00 & 00,0 \\
\hline & Very & 07 & 70,0 \\
\hline & Much more & 03 & 30,0 \\
\hline \multirow{5}{*}{ 2. Increases in quality } & No & 00 & 00,0 \\
\hline & Less & 00 & 00,0 \\
\hline & Moderate & 00 & 00,0 \\
\hline & Very & 01 & 10,0 \\
\hline & Much more & 09 & 90,0 \\
\hline \multirow{5}{*}{ 3. Increases in speed } & No & 00 & 00,0 \\
\hline & Less & 00 & 00,0 \\
\hline & Moderate & 02 & 20,0 \\
\hline & Very & 03 & 30,0 \\
\hline & Much more & 05 & 50,0 \\
\hline \multirow{5}{*}{ 4. Increases in flexibility } & No & 00 & 00,0 \\
\hline & Less & 00 & 00,0 \\
\hline & Moderate & 00 & 00,0 \\
\hline & Very & 06 & 60,0 \\
\hline & Much more & 04 & 40,0 \\
\hline \multirow{5}{*}{ 5. Enter new markets } & No & 00 & 00,0 \\
\hline & Less & 00 & 00,0 \\
\hline & Moderate & 02 & 20,0 \\
\hline & Very & 03 & 30,0 \\
\hline & Much more & 05 & 50,0 \\
\hline \multirow{5}{*}{ 6. Increased competitiveness of the business } & No & 01 & 10,0 \\
\hline & Less & 00 & 00,0 \\
\hline & Moderate & 00 & 00,0 \\
\hline & Very & 03 & 30,0 \\
\hline & Much more & 06 & 60,0 \\
\hline \multirow{5}{*}{ 7. Increased product variety } & No & 00 & 00,0 \\
\hline & Less & 01 & 10,0 \\
\hline & Moderate & 01 & 10,0 \\
\hline & Very & 04 & 40,0 \\
\hline & Much more & 04 & 40,0 \\
\hline \multirow{5}{*}{ 8. Prevented wastes } & No & 00 & 00,0 \\
\hline & Less & 00 & 00,0 \\
\hline & Moderate & 01 & 10,0 \\
\hline & Very & 05 & 50,0 \\
\hline & Much more & 04 & 40,0 \\
\hline \multirow{5}{*}{ 9. Business has won a more dynamic structure } & No & 00 & 00,0 \\
\hline & Less & 00 & 00,0 \\
\hline & Moderate & 04 & 40,0 \\
\hline & Very & 04 & 40,0 \\
\hline & Much more & 02 & 20,0 \\
\hline \multirow{6}{*}{ 10. Business has won a vertical growth } & No & 01 & 10,0 \\
\hline & Less & 00 & 00,0 \\
\hline & Moderate & 02 & 20,0 \\
\hline & Very & 05 & 50,0 \\
\hline & Much more & 02 & 20,0 \\
\hline & Total & 10 & 100.0 \\
\hline
\end{tabular}

